\title{
IMPLEMENTASI METODE REP - IBP \\ DALAM ESTIMASI ERROR PADA PELAT LENTUR DENGAN ELEMEN DKMQ \\ UNIVERSITAS MUHAMMADIYAH TANGERANG
}

\author{
Almufid \\ Dosen Teknik Sipil \\ Fakultas Teknik \\ Universitas Muhammadiyah Tangerang \\ almufid_st@yahoo.com
}

\begin{abstract}
ABSTRAK
Dalam tulisan ini akan dibahas penerapan metode pemulihan gaya dalam yaitu REP (Recovery By Equilibrium In Patches) yang diperkenalkan oleh Zienkiewicz-Zhu untuk problem pelat lentur dengan menggunakan elemen DKMQ (Discrete Kirchoff Mindlin Quadrilateral). Penulisan kali ini akan menggunakan metode Interfaced Base Patch sebagai cara untuk pembentukan patch. Metode ini digunakan untuk memperoleh solusi gaya dalam yang lebih baik dengan memanfaatkan konsep titik superkonvergen. Untuk elemen quadrilateral titik superkonvergen ini berimpit dengan titik integrasi Gauss. Metode REP-Interfaced Based Patch ini kemudian memanfaatkan metode Least Square Fit terhadap titik superkonvergen tersebut untuk memperoleh peningkatan akurasi solusi gaya dalam. Dalam tulisan ini akan disertai pula uji numerik di mana penulis menggunakan tiga metode pemulihan gaya dalam lainnya yaitu metode ratarata langsung, metode proyeksi dan REP- Interfeced Based Patch sebagai perbandingan.

Penelitian akan dilanjutkan dengan menggunakan keempat metode pemulihan gaya dalam yang telah disebutkan di atas sebagai pembentuk estimator error ZienkiewiczZhu $\left(Z^{2}\right)$ untuk mengestimasi error solusi elemen hingga. Pada bagian ini dengan didukung hasil uji numerik kita akan mencoba membuktikan bahwa metode pemulihan gaya dalam REP- Interfaced Based Patch, akan selalu menunjukkan estimasi error yang asimtotik eksak pada contoh kasus yang memiliki solusi eksak maupun yang tidak. Dalam uji numerik tersebut proses modelisasi struktur dilakukan dengan penghalusan jaringan elemen (mesh) tipe- $h$ secara seragam maupun adaptif.

Dalam penelitian ini penulis menggunakan program Finite Element Analysis Program (FEAP) v7.1 sebagai program utama untuk melakukan uji numerik. Dalam program tersebut telah disertai subrutin formulasi elemen DKMQ dan Error Estimator $Z^{2}$ yang ditulis dalam bahasa FORTRAN yang penulis dapatkan dari hasil penelitian sebelumnya. Dalam hal ini penulis cukup menambahkan subrutin yang terkait dengan perhitungan metode REP.
\end{abstract}

Kata Kunci: Pelat Lentur, Elemen DKMQ, Recovery By Equilibrium in Patch, Interfaced Based Patch, Error Estimator, penghalusan tipe- $h$, penghalusan seragam dan adaptif, FEAP 


\section{Pendahuluan \\ 1.Metode Elemen Hingga \\ Permasalah mekanika dapat dijabarkan dan diselesaikan dengan persamaan matematika untuk mendapatkan solusi eksak.} Perkembangan teknologi memunculkan bentuk struktur yang lebih kompleks dan rumit, sehingga perhitungan menggunakan metode eksak akan sulit diterapkan. Karena solusi eksak sulit digunakan, orang mulai mencari beberapa solusi alternatif untuk mendapatkan hasil yang efektif dan efisien dengan metode pendekatan terhadap solusi eksak seteliti mungkin. Oleh karena itu mulai dikembangkan metode numerik yaitu suatu metode yang mentranformasi- kan ekpresi mekanika kontinu menjadi ekspresi mekanika diskrit. Ada beberapa metode yang termasuk dalam metode numerik, yaitu Metode Beda Hingga, Metode Energi, Metode Matriks, dan yang terakhir adalah Metode Elemen Hingga. Pada Metode Elemen Hingga sebuah struktur didiskritisasi menjadi elemenelemen, yang dapat berupa elemen segitiga, segiempat, quadrirateral dan lain-lain. Gabungan elemen-elemen tersebut diharapkan tetap memiliki sifat-sifat struktur yang sebenarnya. Misalnya bentuk geometri, kekakuan, energi dan medan lendutan. Sehingga meskipun metode ini adalah metode pendekatan, hasil yang diperoleh tidak akan banyak berbeda dengan metode eksak.

Estimasi Kesalahan dan
Penghalusan Jaringan Elemen
Metode Elemen Hingga
hanya merupakan solusi pendekatan
dari solusi eksak. Yang menjadi

permasalahannya adalah tidak diketahui solusi eksak yang sesungguhnya, sehingga harus dilakukan pemodelan yang sederhana sehingga dapat diaplikasikan ke model yang lebih kompleks dan rumit. Apabila Modelisasi yang dilakukan kurang tepat, maka akan timbul kesalahankesalahan yang tidak diinginkan. Sumber kesalahan lain dari penggunaan metode elemen hingga antara lain [Z1]:

Pemakaian integrasi numerik dalam pembentukan persamaanpersamaan elemen, seperti matrik kekakuan.Ketidaktepatan penyelesaian secara numerik seperti yang terjadi pada proses iterasi, invers matrik.

Algoritma penyelesaian numerik yang digunakan mempunyai kelemahan pada suatu kasus dan keunggulan tersendiri pada kasus yang lain, sehingga tidak bisa dijamin akan unggul pada setiap kasus, seperti penyelesaian numerik menurut Gauss-Siedel, Newton-Raphson, Runge-Kutta dan sebagainya. Akumulasi kesalahan pembulatan pada proses numerik yang bertahap (efek bola salju).

Kesalahan-kesalahan yang terjadi harus dihitung penyimpangannya agar solusi yang dihasilkan mendekati solusi eksak. Penyimpangan solusi yang disebut dengan error solusi tidak dapat dihindarkan bila menggunakan metode elemen hingga. Pada suatu problem yang kompleks dan rumit akan sulit diketahui atau tidak ada solusi eksaknya, sehingga penyimpangan yang terjadi juga akan sulit diketahui. Untuk itu dibangun sebuah estimator error yang akan membantu mencari solusi yang sedekat mungkin dengan solusi eksak. Hasil perhitungan akan 
mendekati solusi eksak apabila estimator error memberikan hasil yang kecil.

Namun hanya dengan mengetahui berapa tingkat kesalahan tersebut tidaklah cukup, tetapi perlu pula suatu metode yang dapat memperkecil tingkat kesalahan tersebut. Hal ini dapat dilakukan dengan metode yang dinamakan sebagai penghalusan jaringan/mesh elemen hingga. Melalui metode ini dengan bantuan informasi dari hasil analisa estimasi kesalahan dapat diketahui bagaimana mesh elemen yang ada harus dimodelilasisi ulang untuk memperkecil tingkat kesalahan solusi sampai batas yang dapat diterima. Bahkan saat ini metode tersebut telah dikembangkan sedemikian rupa dimana penghalusan jaringan elemen tersebut dapat dilakukan secara otomatis setelah mendapatkan informasi mengenai tingkat kesalahan yang terjadi sehingga dapat meminimalisasi usaha perhitungan Estimasi Kesalahan dan Penghalusan Jaringan Elemen

\section{LATAR BELAKANG HISTORIS}

Hasil dari perkembangan metode elemen hingga adalah penemuan suatu metode estimasi yang dinamakan estimasi kesalahan $a$ posteriori pada akhir tahun 1970 yang diperkenalkan oleh Babuska [B1] (1978) dan Ladeveze [L1] (1977), dimana Ladeveze memperkenalkan terlebih dahulu pemahaman tentang error. Saat ini metode estimasi kesalahan $a$ posteriori dapat diklasifikasikan menjadi dua kategori yaitu :
Estimator berdasarkan kesalahan kesetimbangan atau equilibrum defaults (kesetimbangan residual, interelement traction jump, surface traction defaults) pada solusi elemen hingga.

Estimator berdasarkan post-processing techniques dari solusi elemen hingga (melakukan pendekatan terhadap tegangan eksak, lendutan eksak, turunan fungsi medan lendutan, dan lain-lain).

Metode estimasi ini dapat dilakukan pada tingkat global dan lokal. Dalam tingkat global, besarnya kesalahan dihitung dengan resolusi persamaan pada tingkat global yang merepresentasikan problem struktur yang ditinjau. Dalam tingkat lokal, perhitungan estimasi kesalahan dilakukan pada domain yang merupakan bagian dari domain keseluruhan struktur (misalnya pada nodal-nodal, domain elemen-elemen, atau pada elemen itu sendiri).

Untuk metode global sendiri sudah sering dipakai sejak tahun 1978, yang memiliki sifat:

Diukur dalam bentuk norma energi

Tidak ada informasi mengenai solusi pada tingkat lokal

Tidak terlalu sulit dalam melakukan komputasinya

Metode global ini telah dikembangkan menjadi dua kategori yaitu :

Metode pemulihan (Recovery Method) Menggunakan prosedur postprocessing technique dari solusi yang didapatkan dari metode elemen hingga untuk memulihkan gradien (tegangan) dan menghitung perbedaan antara nilai gradien yang diperoleh dari metode pemulihan terhadap nilai gradien dari 
metode elemen hingga sebagai pendekatan estimasi kesalahan eksak Metode residual (Residual Method), oleh Babuska, Oden, Verfurth [B2,01,V1]

Untuk mengestimasi kesalahan dikembangkan suatu metode pengestimasi kesalahan agar solusi elemen hingga yang dihasilkan mendekati solusi "eksak". Pertamatama Babuska dan Rheinboldt [B1] memprediksi error solusi elemen hingga dengan memanfaatkan residual hasil persamaan keseimbangan dan residual derivatif normal yang terbentuk pada batas-batas antar elemen. Residual yang dihasilkan tersebut merupakan faktor dominan untuk mengestimasi solusi elemen hingga, khususnya pada kasus 1 dimensi. Kemudian Gago [G1,G2] mengembang- kan metode ini untuk problem 2D dan menambahkan interelement traction jumps ke dalam formulasinya. Sebuah interpretasi terhadap Gago estimator telah dilakukan oleh Zhong [Z2] dan Beckers [B3] yang menunjukkan bahwa Gago estimator terlalu heuristic. Maka kemudian estimator eksplisit yang baru di kembangkan dimana surface traction defaults dimasukkan dalam analisanya dan melahirkan teknik estimasi interelemen tractions eksak.

Kikuchi [K1] memperkenalkan estimasi penurunan peralihan dengan solusi elemen hingga (estimasi kesalahan interpolasi). Zienkiewicz dan Zhu [Z1] membangun medan tegangan kontinu dari medan tegangan elemen elemen hingga dengan metode proyeksi global (estimasi lama Zienkiewicz dan Zhu), metode massa tergumpal (lump mass), metode nodal rata-rata, dan metode superkonvergensi (estimasi baru Zienkiewicz dan Zhu). Beckers [B3] menggunakan metode residual wait dan ekstrapolasi untuk membangun medan tegangan kontinu dan metode konstruksi dari medan peralihan derajat superior. Kesimpulan yang dapat diambil adalah:

Estimasi lama dari $Z^{2}$ tidak baik untuk elemen isoparametrik derajat genap, tapi sangat bagus untuk elemen pelat DKQ. Metode massa tergumpal (lump mass), demikian pula metode lainnya, dengan cara rata-rata sederhana tidak baik untuk elemen derajat superior atau sama dengan dua.

Estimasi baru $Z^{2}$ serta metode residual wait dan ekstrapolasi, baik dalam berbagai kasus.

\section{ERROR ESTIMATOR}

Estimasi error a posteriori terus berkembang karena lebih mudah dan efisien. Prudhomme dan Oden [P1] memperkenalkan strategi baru dalam aplikasi estimasi error a posteriori. Mereka memperkenalkan suatu teknik yang dapat meningkatkan reliabilitas estimasi error a posteriori dengan menggunakan metode implicit error residual untuk mencari batas bawah (lower bound) dari estimasi error. Tujuan dari penelitian ini adalah untuk membangun sebuah alat yang dapat memverifikasi akurasi dari solusi metode elemen hingga.

Bernardi [B4] pada tahun 2003 memperkenalkan aplikasi-aplikasi terbaru mengenai estimasi error $a$ posteriori terutama dalam hal adaptifitas jaringan (mesh) elemen. 
Salah satu aplikasi yang diperkenalkan nya adalah aplikasidiskritisasi bertahap. Kedua penelitian diatas masih bersifat hipotesa sehingga diperlukan penelitian lebih lanjut. Oleh karena itu dikesempatan ini penulis sengaja memilih error estimasi Zienkiewicz-Zhu [Z3] dikarena-kan aplikasinya sudah banyak digunakan dan diterima sebagai metode yang sangat baik didukung dengan kemudahan dalam komputasi nya dan implementasinya pada komputer.

Dengan proses recovery baru, prosedur estimasi error berdasarkan teknik pemulihan memberikan hasil yang terbaik ketika dilakukan pengujian pada berbagai bentuk problem pelat. Bagaimanapun Babuska, dalam deretan penerbitan mulai 1994 yang memperkenalkan banyak pengujian objektif terhadap error estimator dan menciptakan suatu pengujian berbagai bentuk error estimator dimana termasuk didalamnya teknik pemulihan error estimator menggunakan metode SPR, yang menjadi pengujian terbaik untuk saat ini.

Metode superkonvergen berikutnya, yang diperkenalkan oleh Boroomand [B5, B6] yang disebut REP (Recovery by Equilibrium in Patches), pada dasarnya menggunakan pembentukan patch elemen juga. Metode ini menggunakan persamaan keseimbangan dari formulasi solusi untuk menghasilkan medan gaya dalam yang dipulihkan. Kemudian metode ini ditingkatkan [B7], dan membuktikan bahwa metode ini lulus test yang diperkenalkan Babuska [B8-B10]. Tidak seperti metode SPR yang memerlukan informasi tentang titik superkonvergen yang berda di seluruh elemen pembentuk patch, REP tidak memerlukannya, metode REP hanya menggunakan titik boundaries yang ada pada elemen. Untuk prosedur perhitungannya secara keseluruhan hampir sama dengan SPR.

\section{TEKNIK PEMULIHAN SOLUSI}

Solusi perhitungan gaya dalam merupakan suatu hasil yang penting dalam aplikasi teknik sipil. Perhitungan solusi pada umumnya dilakukan pada nodal-nodal elemen, dimana meliputi peralihan (lendutan) nodal, gaya dalam nodal, tegangan dan regangan. Nilai peralihan untuk sebuah model peralihan elemen hingga umumnya memberikan konvergensi error sesuai dengan orde polinomial pembentuk elemen tersebut. Namun untuk nilai gradien atau turunan dari peralihan tersebut, seperti gaya dalam dan tegangan/regangan, umumnya memiliki konvergensi error yang lebih kecil. Oleh karena itu sebuah model elemen hingga perlu dilengkapi sebuah metode yang dapat memperbaiki solusi tersebut dengan akurasi tinggi. Metode ini dikenal luas sebagai teknik pemulihan solusi.

Dengan media error estimator, kita dapat mengetahui tingkat akurasi dan konvergensi sebuah metode pemulihan solusi yang dipakai. Hingga saat ini sudah banyak teknik pemulihan solusi yang dikemukakan oleh berbagai peneliti di dunia, Salah satu metode yang dikenal luas sebagai teknik pemulihan solusi yang baik adalah Recovery by Equilibrium In Patches. 


\section{TUJUAN Dan METODOLOGI PENULISAN}

Dalam Jurnal ini, akan dievaluasi performa elemen kuadrilateral pelat empat nodal dengan masing-masing tiga derajat kebebasan yang diberi nama MITC[B6] (Mixed Interpolated Tensorial Components) melalui penerapan error estimator dengan metode estimasi Zienkiewicz-Zhu [Z4] atau estimasi $Z^{2}$ dengan teknik pemulihan solusi gaya dalam Recovery by Equilibrium In Patch (REP) menggunakan metode element Interfaced based patch. Selain itu menggunakan metode proyeksi gaya dalam, rata-rata langsung dan SPRnodal based patch sebagaipembanding.

Penerapan dari metode estimasi kesalahan $Z^{2}$ ini adalah untuk menunjukkan bagaimana mengestimasi presisi dari solusi elemen tersebut dan bagaimana merealisasikan presisi tersebut dengan menggunakan jaringan adaptif, sehingga akhirnya diperoleh pemodelan elemen hingga yang mendekati optimal atau mendekati struktur fisik sebenarnya dengan usaha komputasi yang minimal, sehingga hasil yang diperoleh memenuhi batas akurasi yang ditentukan. Selain untuk mengestimasi error pada suatu tahap diskritisasi, error estimator ini juga akan digunakan untuk mengetahui tingkat akurasi dari teknik pemulihan gaya dalam yang digunakan sebagai parameter utama pembentuk error estimator $Z^{2}$.Metodologi penelitian yang digunakan adalah berupa studi literatur dari berbagai buku dan jurnal yang ada di daftar pustaka. Analisa dan test akan dilakukan dengan menggunakan main program FEAP versi
7.1 (Finite Element Analysis Program) yang dibuat oleh R.L. Taylor, dan akan dibuat subrutin teknik pemulihan gaya dalam REP. Untuk metode error estimasi dan teknik pemulihan gaya dalam lainnya sudah tersedia subrutinnya berkat penelitian sebelumnya sehingga pada penelitian kali ini penulis hanya menggunakannya dengan sedikit modifikasi untuk menyesuaikan dengan metode REP. Penjelasan mengenai formulasi elemen MITC[B6] serta implementasinya pada FEAP dapat dilihat pada daftar referensi[K3]

\section{PEMBATASAN MASALAH}

Masalah yang akan dibahas dibatasi hanya untuk elemen pelat quadrilateral 12 derajat kebebasan, dengan material homogen, isotropik dan linier elastik dengan tipe pembebanan statis. Untuk aplikasi estimasi kesalahan, evaluasi pada proses diskritisasi dilakukan dengan penghalusan jaringan secara seragam dan adaptif. Estimasi kesalahannya menggunakan metode REP (Recovery Equilibrium In Patch) yang dikembangkan oleh ZienkiewiczZhu[Z3],yang menggunakan metode Element Interface Based Patch.

\section{MODIFIKASI SUBRUTINE UI-FEAP}

Implementasi metode REP pada program UI-FEAP merupakan sebuah modifikasi pada paket program UI-FEAP yang perlu dilakukan untuk menunjang kegiatan penelitian kali ini. Implementasi ini bersifat user based solution program yang artinya implementasi tersebut tidak melibatkan modifikasi struktur baku UIFEAP secara signifikan dan dapat 
dimodifikasi MODIFIKASI SUBRUTINE UIFEAP

Implementasi metode REP pada program UI-FEAP merupakan sebuah modifikasi pada paket program UI-FEAP yang perlu dilakukan untuk menunjang kegiatan penelitian kali ini. Implementasi ini bersifat user based solution program yang artinya implementasi tersebut tidak melibatkan modifikasi struktur baku UI-FEAP secara signifikan dan dapat dimodifikasi lebih lanjut tanpa mengganggu struktur program yang dibuat oleh user lain.

Seperti yang sudah dijelaskan sebelumnya bahwa UI-FEAP melibatkan tiga modul dalam melakukan proses komputasi metode elemen hingga Dalam implementasi metode REP ini, dilakukan modifikasi pada UI-FEAP pada bagian modul solusi. Oleh karena dalam penelitian kali ini metode REP digunakan pada elemen DKMQ [K2] maka modifikasi program yang dilakukan masih terbatas pada elemen tersebut atau elemen quadrilateral lainnya yang sederajat. Selain itu, karena prosedur REP pada dasarnya sama dengan prosedur SPR yang sudah dibuat oleh peneliti terdahulu, maka banyak subrutin-subrutin SPR yang digunakan dengan atau tanpa modifikasi. Penjelasan mengenai subrutin-subrutin yang dimodifikasi maupun yang baru dapat dilihat pada Subbab dibawah

lebih lanjut tanpa mengganggu struktur program yang dibuat oleh user lain.

Seperti yang sudah dijelaskan sebelumnya bahwa UI-FEAP melibatkan tiga modul dalam melakukan proses komputasi metode elemen hingga . Dalam implementasi metode REP ini, dilakukan modifikasi pada UI-FEAP pada bagian modul solusi. Oleh karena dalam penelitian kali ini metode REP digunakan pada elemen DKMQ [K2] maka modifikasi program yang dilakukan masih terbatas pada elemen tersebut atau elemen quadrilateral lainnya yang sederajat. Selain itu, karena prosedur REP pada dasarnya sama dengan prosedur SPR yang sudah

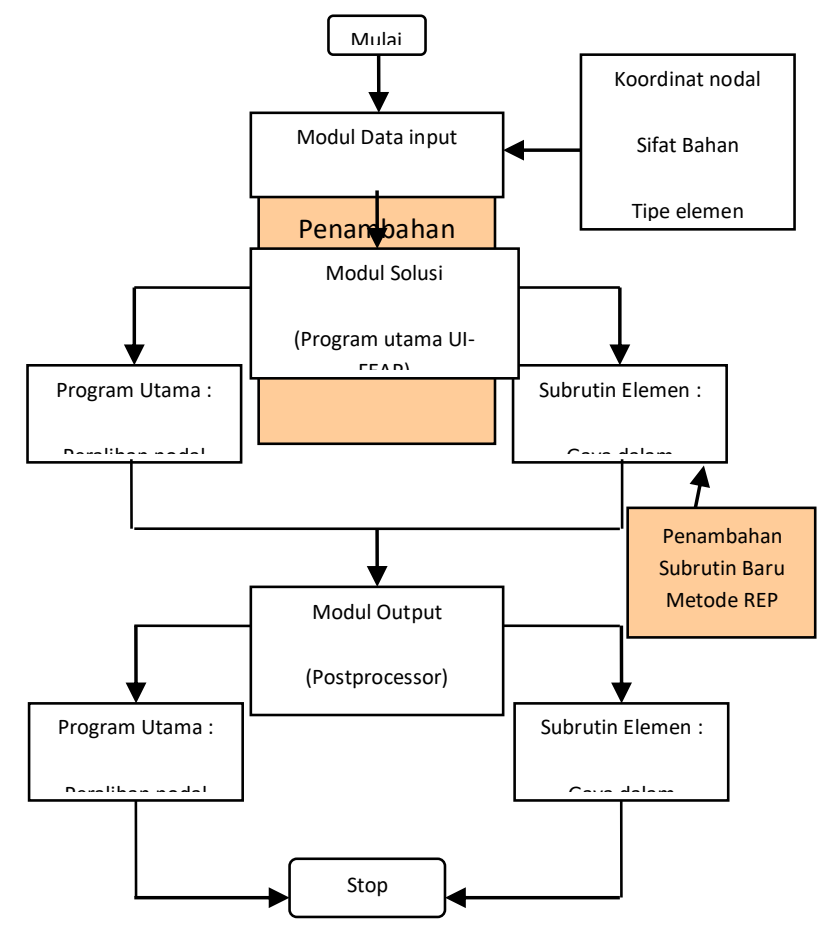

Gambar Modifikasi secara umum yang dilakukan pada UI-FEAP untuk aplikasi metode REP

Perintah-perintah makro tersebut ditulis pada subrutin berikut ini :

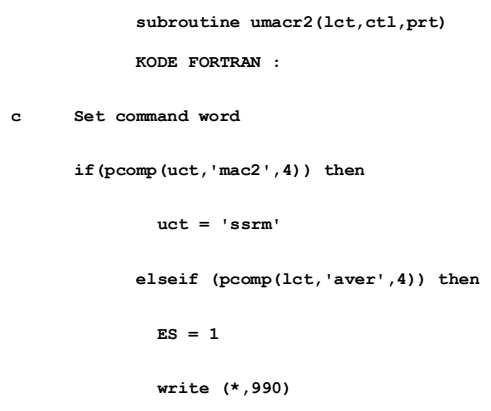




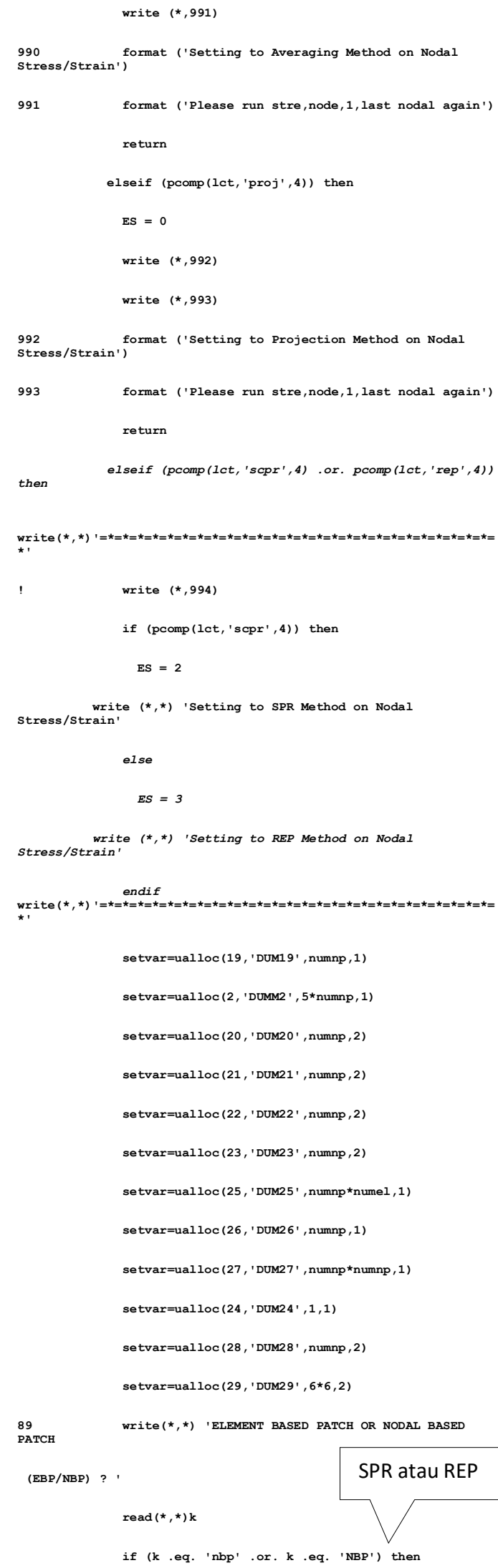

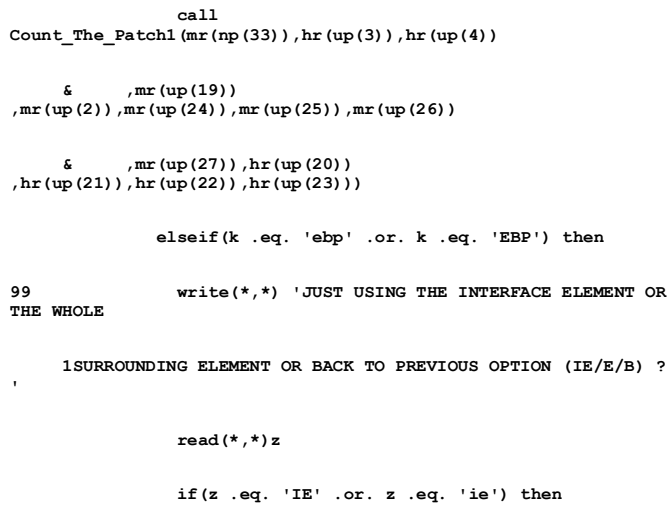

ini akan menampilkan bebarapa hasil dari uji numerik dari berbagai kasus pelat. Yang akan dilakukan adalah pengujian terhadap implementasi teknik pemulihan gaya dalam dan pengujian terhadap error estimator $Z^{2}$. Tujuan dilakukan uji numerik ini adalah untuk mengetahui sifat dan perilaku error estimator $Z^{2}$ dan teknik pemulihan gaya dalam REP pada elemen DKMQ[K2] seperti 
tingkat akurasi dan kecepatan konvergensi error.

Uji numerik yang dilakukan terbagi menjadi dua bagian utama. Bagian pertama akan membahas implementasi teknik pemulihan gaya dalam menggunakan metode REP-Interface Based Patch dan dibandingkan dengan metode SPR-Element Based Patch, metode SPRNodal Based Patch,Element Based Patch, metode rata-rata dan metode proyeksi.

Pada bagian kedua kita akan meninjau pengujian terhadap estimasi error menggunakan error estimator $Z^{2}$. Pada bagian ini kita akan terfokus pada beberapa parameter utama estimasi error berdasarkan berbagai macam variasi bentuk geometri, pembebanan, dan kondisi batas dari problem struktur yang ditinjau. Kemudian dilakukan perbandingan antara metode REP-Element Based Patch dengan metode SPR-Element Based Patch, metode SPR-Nodal Based Patch, Metode SPR-Interface Based Patch metode ratarata dan metode proyeksi. Parameterparameter utama estimasi error tersebut antara lain :

1. Estimasi error dalam bentuk norma energi secara global (predicted global energy norm error) yaitu $\left\|e^{*}\right\|$

2. Indikator error relatif struktur dalam norma energi (predicted relative global energy norm error) yaitu $\phi^{*}$ (\%)

3. Indikator penghalusan lokal dalam norma energi (mesh refinement indicator) yaitu $\zeta$

\section{Problem Error pada REP}

Indikator error relatif pada metode REP untuk pelat lentur DKMQ menunjukkan hasil yang mengejutkan jika tidak dilakukan pembatasan patch, di mana patch eksternal juga digunakan dalam

perhitungan. Meskipun persentase error untuk momen lentur menunjukkan hasil yang lebih baik dibandingkan metode lain, indikator error relatif yang dihasilkan memberikan hasil yang sangat tinggi. Angka indikator error yang relatif yang tinggi tersebut disumbang oleh komponen geser, di mana hasil perhitungannya sangat sensitif terhadap bentuk elemen. Ini bisa dilihat pada subbab Distribusi Gaya Geser dan Momen Lentur dalam bab ini. Hal ini sebenarnya juga sudah diindikasikan dalam penelitian oleh Boroomand [B9], yang dalam uji numerik untuk pelat lentur dengan elemen MITC memang menunjukkan hasil yang kurang bagus untuk komponen geser. Baik MITC maupun DKMQ memang dilatarbelakangi tujuan untuk menyelesaikan persoalan efek shear locking, sehingga akurasi tegangan geser tidak dianggap penting.

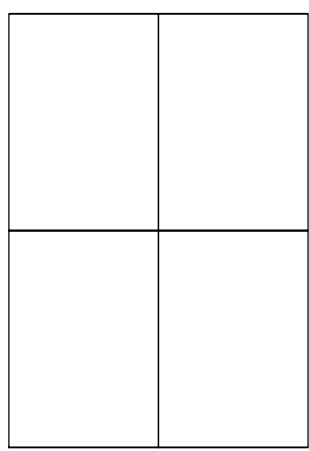

Gambar

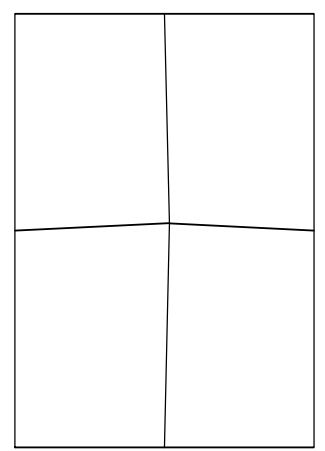

4.1 Elemen Bujursangkar Memberikan Hasil Indikator Error yang Fluktuatif, Sedikit Perubahan Geometri Memberikan Hasil Indikator Error Relatif yang Normal

Dalam kasus DKMQ, faktor bentuk sangat berpengaruh, di mana pada meshing elemen bujursangkar, indikator error relatif besarnya fluktuatif, kadangkadang hasilnya bisa jauh dari indikator error relatif dengan metode-metode lain. Dalam kasus pelat bujur sangkar, penulis menguji elemen pelat yang sedikit diubah bentuknya. Sebagai contoh adalah seperti pada Gambar 4.3a untuk meshing $2 \times 2$. Modifikasi konfigurasi meshing tersebut 
akan memberi angka yang sangat dekat dengan hasil SPR dan tidak fluktuatif.

Penyebab masalah tersebut adalah ketidaktepatan hasil penyelesaian numerik pada proses invers matriks berkaitan dengan bilangan-bilangan yang sangat kecil dengan tingkat ketelitian melampaui kemampuan komputer.

Telah lebih lanjut menunjukkan bahwa masalah di atas ternyata bisa diatasi dengan membatasi pemakaian patch, di mana hanya internal patch saja yang digunakan. Penggunaan internal patch dengan jumlah elemen anggota patch minimal 5 ternyata bisa memperbaiki error pada komponen geser, meskipun masih menyimpang jika dibandingkan dengan hasil perhitungan dengan metode lain. Barulah setelah pembatasan dilakukan dengan penggunaan internal patch dengan jumlah elemen anggota patch minimal 7 , hasil pemulihan momen, geser dan indikator error relatif sangat dekat dengan hasil metode-metode lain untuk pelat tebal. Perbandingannya bisa dilihat pada subbab Distribusi Gaya Geser dan Momen Lentur untuk Pelat Lingkaran.

\section{Uji Konvergensi Gaya Dalam Dan Estimasi Error}

Pada bagian ini akan dibahas uji konvergensi gaya dalam dan estimasi error menggunakan lima metode pemulihan gaya dalam. Sebelumnya penelitian sudah dilakukan untuk empat metode. Dalam pengujian ini ditambahkan metode REPElement Based Patch.

Keterangan yang diperlukan:
REP nbp = metode REP- Element Nodal Based Patch, dengan minimal 3 elemen dalam satu patch

REP ebp = metode REP- Element Based Patch, dengan minimal 5 elemen dalam satu patch

REP ibp, REP = metode REP- Element Interface Based Patch, dengan minimal 7 elemen dalam satu patch (hanya memakai internal patch)

SPR nbp = metode SPR-Nodal Based Patch

SPR ebp = metode SPR-Element Based Patch

AVR = metode rata-rata langsung

PRJ = metode proyeksi

Persentase error (\%)

NELT = jumlah elemen

\section{Pelat Bujursangkar Perletakan Jepit dengan Beban Merata}

Pelat bujur sangkar adalah contoh kasus yang banyak ditemukan dalam aplikasi bidang sipil. Penghalusan dilakukan secara seragam dimulai dari mesh $2 \times 2,4 \times 4,8 \times 8$, $16 \times 16$. Solusi gaya dalam eksak untuk kasus perletakan jepit adalah [A2]:

- $\quad$ Momen di pusat pelat

$M=0,0231 f_{z} L^{2}$

- Momen di tengah tepi pelat :

$M=0,0513 f_{z} L^{2}$ 


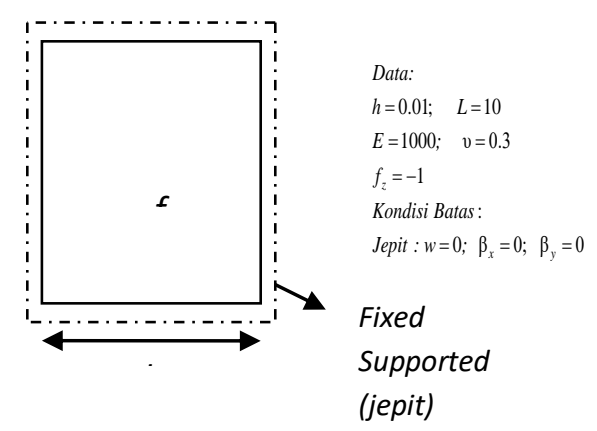

Gambar 4.2 Pelat bujursangkar bertumpuan jepit dengan beban terbagi merata

\section{Konvergensi Gaya Dalam}

Tabel 4.1 Momen lentur di pusat pelat

bujursangkar perletakan jepit

\begin{tabular}{|c|c|c|c|c|c|c|c|}
\hline \multirow{2}{*}{ NELT } & \multicolumn{7}{|c|}{ Momen Lentur Pusat } \\
\cline { 2 - 8 } & $\begin{array}{l}\text { REP } \\
\text { ibp }\end{array}$ & $\begin{array}{l}\text { REP } \\
\text { nbp }\end{array}$ & $\begin{array}{l}\text { REP } \\
\text { ebp }\end{array}$ & $\begin{array}{l}\text { SPR } \\
\text { nbp }\end{array}$ & $\begin{array}{l}\text { SPR } \\
\text { ebp }\end{array}$ & AVR & PRJ \\
\hline 4 & 1.0486 & 1.1158 & 1.1931 & 1.625 & 1.625 & 4.875 & 1.0833 \\
\hline 16 & 2.382 & 2.4181 & 2.4023 & 2.3047 & 2.4842 & 2.8735 & 2.1283 \\
\hline 64 & 2.323 & 2.31796 & 2.3114 & 2.3324 & 2.3027 & 2.4331 & 2.2597 \\
\hline 256 & 2.30532 & 2.30132 & 2.3028 & 2.3038 & 2.3019 & 2.326 & 2.2834 \\
\hline Eksak & & & & 2.31 & & & \\
\hline
\end{tabular}

\begin{tabular}{|c|c|c|c|c|c|c|c|}
\hline \multirow{2}{*}{ NELT } & \multicolumn{6}{|c|}{ Persentase Error gaya dalam Momen (\%) } \\
\cline { 2 - 8 } & $\begin{array}{c}\text { REP } \\
\text { ibp }\end{array}$ & $\begin{array}{l}\text { REP } \\
\text { nbp }\end{array}$ & $\begin{array}{l}\text { REP } \\
\text { ebp }\end{array}$ & $\begin{array}{l}\text { SPR } \\
\text { nbp }\end{array}$ & $\begin{array}{l}\text { SPR } \\
\text { ebp }\end{array}$ & $\begin{array}{l}\text { AV } \\
\text { R }\end{array}$ & PRJ \\
\hline 4 & $\begin{array}{c}54.6060 \\
6\end{array}$ & 51.69697 & 48.350 & 29.6537 & 29.6537 & 111.039 & 53.1026 \\
\hline 16 & $\begin{array}{c}3.11688 \\
3\end{array}$ & 4.679653 & 3.9957 & 0.2294 & 7.5411 & 24.3939 & 7.8658 \\
\hline 64 & $\begin{array}{c}0.56277 \\
0\end{array}$ & $\begin{array}{c}0.344588 \\
7\end{array}$ & 0.0606 & 0.9697 & 0.316 & 5.329 & 2.1775 \\
\hline 256 & $\begin{array}{c}0.20259 \\
7\end{array}$ & $\begin{array}{c}0.375757 \\
6\end{array}$ & 0.3117 & 0.2684 & 0.3506 & 0.6926 & 1.1515 \\
\hline
\end{tabular}

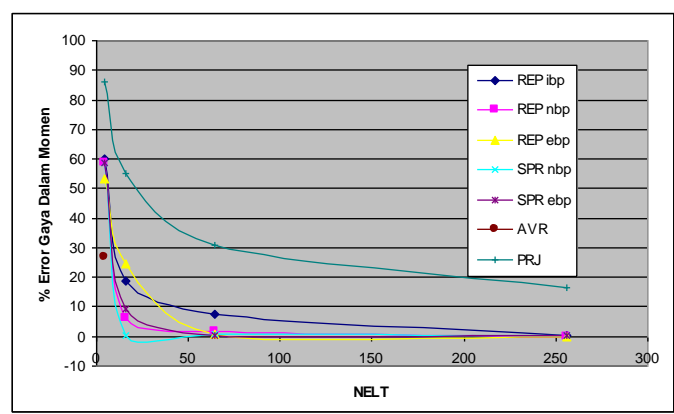

Gambar 4.3 Persentase Error Momen Lentur Di Tengah Sisi Atau Perletakan Pelat Bujur Sangkar Perletakan Jepit

\section{Pelat Melingkar dengan Beban Merata}

Pada bagian ini akan dibahas uji konvergensi solusi gaya dalam pada pelat lingkaran dengan perletakan sendi (soft simply supported, $w=0$ ) dan jepit

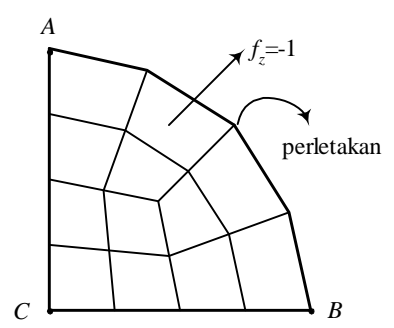

Data :

$E=1000 ; v=0.3$

$R=50 ; t=1$

Beban terbagi rata $: f_{z}=-1$

Kondisi batas :

Sendi : $w=0$

Jepit : $w=\beta_{x}=\beta_{y}=0$

Kondisi simetri :

Sisi $C B: \beta_{y}=0$

Sisi $C A: \beta_{x}=0$

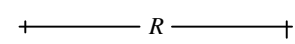

(clamped, $w=\beta_{x}=\beta_{y}=0$ ) pada sekeliling pelat dengan pembebanan merata. Tujuan dari uji ini adalah untuk mengetahui perilaku keempat teknik pemulihan gaya dalam pada konfigurasi elemen yang non rektangular. Analisa struktur dibatasi pada $1 / 4$ bagian saja karena sifat simetrisnya, seperti yang terlihat pada Gambar 4.4. 
Gambar 4.4 1/4 bagian dari pelat

lingkaran dengan beban terbagi rata

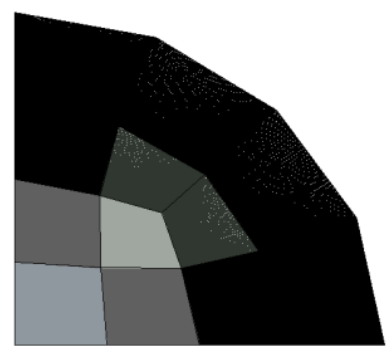

Mesh seragam no. $2($ NELT $=12)$

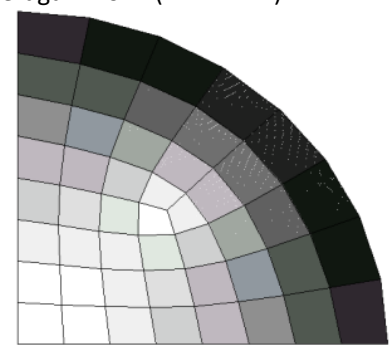

Mesh seragam no. $3(\mathrm{NELT}=48)$

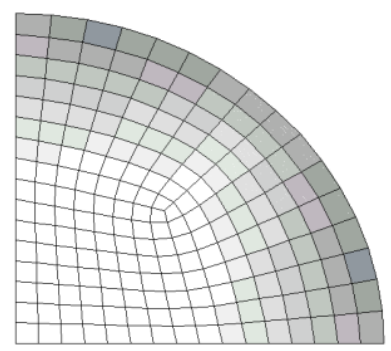

Mesh seragam no. $4($ NELT $=192)$

Gambar 4.5 Skema Penghalusan Seragam Untuk Pelat Melingkar

\section{Perletakan Jepit:}

Tabel 4.2 Momen Lentur Dan Error Gaya Dalam di Pusat Pelat Melingkar Perletakan Jepit - Penghalusan Seragam

\begin{tabular}{|c|c|c|c|c|c|c|c|}
\hline \multirow[b]{2}{*}{ NELT } & \multicolumn{7}{|c|}{ Momen Lentur Pusat } \\
\hline & $\begin{array}{l}\text { REP } \\
\text { ibp }\end{array}$ & $\begin{array}{l}\text { REP } \\
\text { nbp }\end{array}$ & REP ebp & SPR nbp & SPR ebp & AVR & PRJ \\
\hline 3 & $\overline{177.60}$ & 178.87 & 201.23 & 215.58 & 215.47 & 254.2 & 182.02 \\
\hline$\overline{12}$ & 193.50 & $\overline{199.94}$ & 203.64 & 202.05 & 201.36 & 214.7 & 198.64 \\
\hline 48 & 203.45 & 203.55 & 203.39 & 203.76 & 203.51 & 206.2 & 201.94 \\
\hline 192 & 203.18 & 203.19 & 203.16 & 203.21 & 203.2 & $\begin{array}{c}203.8 \\
8\end{array}$ & 202.78 \\
\hline Eksak & \\
\hline
\end{tabular}

\begin{tabular}{|c|c|c|c|c|c|c|c|}
\hline \multirow{2}{*}{ NELT } & \multicolumn{7}{|c|}{ Persentase Error gaya dalam Momen (\%) } \\
\cline { 2 - 8 } & $\begin{array}{c}\text { REP } \\
\text { ibp }\end{array}$ & REP nbp & REP ebp & SPR nbp & SPR ebp & AVR & PRJ \\
\hline 3 & 12.5662 & 11.9409 & 53.1618 & 58.577 & 58.577 & 26.9006 & 86.1924 \\
\hline 12 & 4.7385 & 1.5680 & 24.5244 & 0.1481 & 9.0936 & 5.232 & 55.3002 \\
\hline 48 & 0.1600 & 0.2092 & 0.9825 & 0.7271 & 0.5088 & 1.1949 & 30.9084 \\
\hline 192 & 0.0271 & 0.0320 & 0.0117 & 0.3918 & 0.23 & 0.2593 & 16.5127 \\
\hline
\end{tabular}

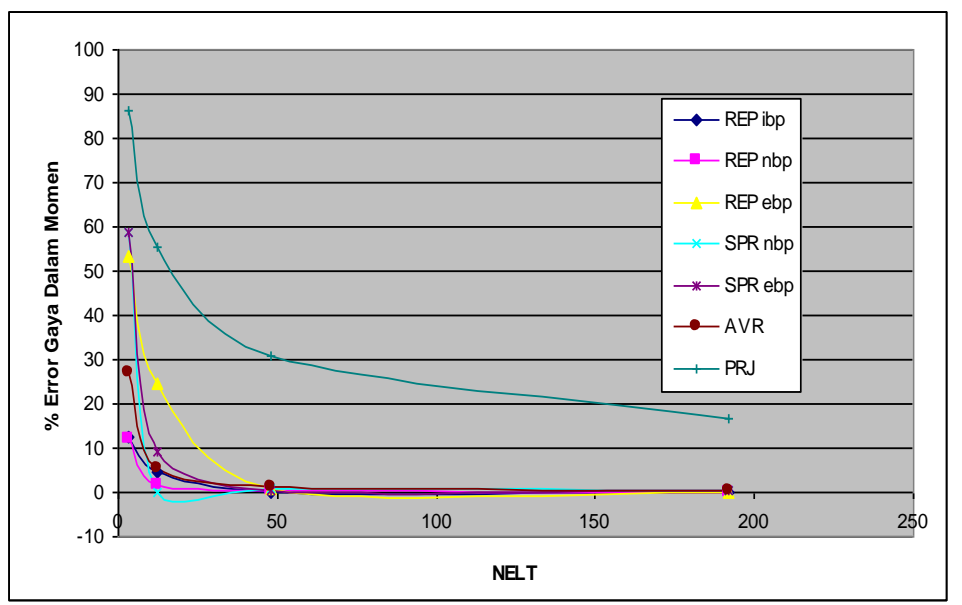

Gambar 4.6 Persentase Error Gaya Dalam Momen di Pusat Pelat Melingkar Perletakan Jepit - Penghalusan Seragam 


\section{KESIMPULAN}

Tujuan Penelitian ini adalah mengkaji implementasi metode REP dalam mengestimasi error hasil analisis metode untuk pelat lentur dengan elemen DKMQ [k2] (Discrete Kirchoff Mindlin Quadrileteral ). Perfoma metode tersebu dibandingkan dengan berbagai metode proyeksi gaya dalam, rata-rata langsung dan metode SPR. Berdasarkan hasil uang diperoleh pada uji numerik, dapat diambil kesimpulan sebagai berikut ;

Konvergensi Solusi Gaya Dalam

Dalam Uji Numerik ini dapat silihat tingkat akurasi dari masing-masing teknik pemulihan solusi gaya dalam yang digunakan. Secara Umum metode REP Interface Based Patch memberikan hasil yang sangat dekat dengan hasil perhitungan metode SPR untuk solusi gaya dalam momen lentur, yang merupakan faktor utama dalam problem pelat lentur. SPR diketahui lebih baik dan stabil dibandingkan dengan metode rata - rata dan metode proyeksi. Tetapi, dalam hal solusi gaya geser, metode REP memberikan hasil yang tidak bagus jika boundery patch ikut digunakan dalam perhitungan. Penggunaan hanya internal patch memberikan pemulihan solusi gaya geser yang baik.

Konvergensi Error berdasarkan Error Estimator $Z^{2}$

Keempat metode pemulihan gaya dalam yang dipakai dapat teradaptasi dengan baik pada error estimator $Z^{2}$. Secara umum metode REP memberikan solusi dengan konvergensi error dengan konvergensi error yang dekat dengan SPR. Tetapi, REP memberikan hasil yang jauh menyimpang dan fluktuatif jika boundary patch ikut digunakan dalam perhitungan.
Penerapan REP interface Based Patch dalam mengestimasi error secara akurat adalah dengan hanya menggunakan internal patch. Dan tidak memakai boundary patch. Yang menghasilkan error relatif geser yang besar.

Uji numerik dalam tesis ini menggunakan elemen DKMQ. Agar bisa didapat kesimpulan yang lebih menyeluruh, perlu dilakukan kajian terhadap metode REP dengan elemen - elemen lain seperti MITC

\section{DAFTAR PUSTAKA}

[A1] Akin, J.E., "Finite Element"(Draft Version), 2004

[B6] Babuska I., Strouboulis T., Uphadyay C.S., Gangaraj S.K. and Copps K., "Validation of A Posteriori Error Estimators by Numerical Approach", Int. J. Num. Meth. Engineering, VOL 37, 10731123, 1994

[B7] Babuska I., Strouboulis T., Uphadyay C.S., "A Model Study of The Quality of A Posteriori Estimators for Linier Eliptic Problems", Comput. Methods Appl. Mech. Eng, Vol 114, 307-378, 1994

[G1] Gago J.P. "A posteriori error analysis and adaptivity for the finite element method", Ph.D. thesis, University of Wales, Swansea, U.K., 1982

[H1] Irwan Katili “ Plate Lenture “ 2005 